\title{
The Role of Psychological Capital on Job Embeddedness and Organizational Cynicism: A Study on Menoufia University Hospitals
}

\author{
Wageeh $\mathrm{Nafei}^{1}$ \\ ${ }^{1}$ University of Sadat City, Egypt \\ Correspondence: Wageeh Nafei, University of Sadat City, Menoufia, Egypt. E-mail: dr.wageeh1965@yahoo.com
}

Received: June 2, 2014 Accepted: December 3, 2014 Online Published: February 20, 2015

doi:10.5539/jms.v5n1p50 URL: http://dx.doi.org/10.5539/jms.v5n1p50

\begin{abstract}
Purpose: The objective of this study was to provide empirical evidence on the relationships between Psychological Capital (PsyCap), Job Embeddedness (JE) and Organizational Cynicism (OC).

Research Design/Methodology: Using Luthans, 2006 of PsyCap, the study develops a number of hypotheses and tests them. Out of the 338 questionnaires that were distributed to employees at Menoufia University hospitals in Egypt, 315 usable questionnaires were returned, a response rate of 93\%.

Findings: The results showed that PsyCap is significantly related to the JE and OC. In other words, self-efficacy, optimism, hope and resilience significantly correlated with JE and OC. The results also supported the hypothesized model. The results refer to a direct effect in the opposite direction between the PsyCap and OC of employees. The study findings support the view that the dimensions of PsyCap were positively related with JE.
\end{abstract}

Practical implications: The study suggests that Menoufia University hospitals in Egypt can improve JE by influencing its PsyCap, specifically, by developing self-efficacy, optimism, hope and resilience. The study provided that it is necessary to pay more attention to the dimensions of PsyCap as a key source for organizations to enhance the competitive advantage which is of prime significance for JE and OC.

Originality/value: Preliminary evidence of the psychometric properties of the PCQ-24, which measures the construct of PsyCap (hope, self-efficacy, resilience and optimism) on an Egyptian sample, was provided in this study.

Keywords: psychological capital, job embeddedness, organizational cynicism

\section{Introduction}

The new concept recently introduced by Luthans is derived from positive organizational behavior (POB) and it is the psychological capital (PsyCap), which can provide sustainable competitive advantage for organizations (Hodges, 2010).

The new kinds of capitals have arisen such as human, social and PsyCap (Irshad \& Toor, 2008). PsyCap has less attention compared to other forms of capital, like human and social capital, research supports its development and management in organizations to increase organizational efficiency, productivity and the successful implementation of organizational change (Luthans et al., 2004).

PsyCap has explored its role in for-profit organizations and researchers should investigate the role of PsyCap in other organizational contexts, like non-profit organizations, hospitals, education institutions and government organizations (Youssef \& Luthans, 2012).

PsyCap may enable individuals to cope with the complexity of careers in the dynamic working environment (Avey et al., 2010). PsyCap has been demonstrated conceptually and empirically to represent an individual's positive psychological state of development (Luthans et al., 2007).

Positive Organizational Scholarship (POS) refers to positively oriented human resource strengths and PsyCap that can be measured, developed, and effectively managed for performance in today's workplace (Luthans \& Church, 2002). PsyCap is the core psychological factor of positivity in general, and POB criteria meeting states in particular, that go beyond human and social capital to gain a competitive advantage through investment/development of 'who you are' (Luthans \& Youssef, 2004). 
The benefits of higher order construct of PsyCap in contemporary organizational settings have been demonstrated in an emerging, yet growing body of research (Youssef \& Luthans, 2010). PsyCap produces higher correlations with performance outcomes than any of its individual components by themselves (Luthans et al., 2005). PsyCap appears to have a synergistic effect, whereby the whole PsyCap may be greater than the sum of its parts (efficacy, hope, optimism and resiliency). PsyCap has been shown to be a developable resource with several empirical studies demonstrating the utility of PsyCap interventions (Luthans et al., 2007; 2008).

Employee attitudes (job satisfaction, organizational commitment and turnover intentions) and employee behaviours (organizational citizenship behaviour and job performance) have been found to be positively related with PsyCap (Avey et al., 2011).

PsyCap can be viewed as "who you are" and "what you can become in terms of positive development" (Avolio \& Luthans, 2006) and is differentiated from human capital ("what you know"), social capital ("who you know"), and financial capital ("what you have") (Luthans et al., 2004).

PsyCap has its roots in the optimistic psychology. The purpose of optimistic psychology is to use the scientific methods to discover the factors that lead to growth and progress of individuals, groups, organizations, and communities (Luthans, 2010). The capacities of the optimistic organizational behavior should include the contracts that are measurable and developable and depends on the work for its improvement (Nelson \& Cooper, 2007). The capacities of optimistic organizational behavior include hopefulness, optimism, flexibility, and self-efficiency. All these factors represent the PsyCap (Luthans \& Youssef, 2004).

PsyCap has considerable positive effects on the organizational desirable outcomes. PsyCap leads to increase in creativity and entrepreneurship; decrease in work absence; increase in performance, organizational commitment, job satisfaction, and organizational citizenship behavior. PsyCap includes actualization and development of the employees' talent and potentials (Toor \& Ofori, 2010). This also is educable and has favorite return on investment (Luthans et al., 2008; 2010).

PsyCap changes overtime, for instance, employees who demonstrated an increase (or decrease) in PsyCap showed an increase (or decrease) in performance (Peterson et al., 2011). Organizational commitment and job satisfaction have been found to be positively related with PsyCap (Cetin, 2011). PsyCap is one of the most influential means in attaining the desired organizational performance (Lewis, 2011). PsyCap positively relates to the level of trust in organization (Clapp-Smith et al., 2009). PsyCap helps overcome stress and facilitate positive organizational change (Avey et al., 2008). Organizational performance can be an outcome of developing and managing the PsyCap factors of hope, resilience, optimism and self-efficacy (Luthans et al., 2007).

In sum, PsyCap is presented here as an emerging higher order, core construct that organizations can invest in and develop in their workforce to achieve veritable, sustained growth and performance. PsyCap may help provide and contribute to the call for a new perspective and approach to managing for competitive advantage in the "flat world" environment. However, PsyCap cannot operate in vacuum and this is why we hope that a supportive organizational climate may play a role.

\section{Literature Review}

\subsection{Psychological Capital}

PsyCap is identified as personal traits contributing to individual productivity by psychologists (Gohel, 2012).

It is the study and application of positively oriented human resource strengths and psychological capacities that can be measured, developed, and effectively managed for performance improvement in today's workplace (Luthans et al., 2007).

PsyCap is an individual's positive psychological state of development, characterized by (1) having confidence (self-efficacy) to take on and put in the necessary effort to succeed at challenging tasks, (2) making a positive attribution (optimism) about succeeding now and in the future, (3) persevering towards goals and, when necessary, redirecting paths to goals (hope) to succeed, and (4) when beset by problems and adversity, sustaining and bouncing back and even beyond (resiliency) to attain success" (Luthans \& Youssef, 2007).

There are several important points of PsyCap. They are (1) it is dependant on positive psychology paradigm (strong aspects of human), (2) it involves psychological situations based on positive organizational behavior or positive organizational behavior criteria (unique, theory and research based, valid measure and state-like), (3) it goes beyond human capital ("what we know") and social capital (for example, "who we know") while expressing "who we are", and (4) comprises investments and improvements that lead to performance development and competitive advantage (economical and financial capital) (Luthans et al., 2005). 
PsyCap is seen as a resource that goes beyond human capital (experience, knowledge, skills and abilities) and social capital (relationships, networks). It deals with "who you are here and now", and "who you can become" in the proximal future if your resources are developed and nurtured in the workplace (Luthans et al., 2004).

\subsection{The Basic Components of PsyCap}

There are four components into PsyCap. They are self-efficacy/confidence, hope, optimism, and resiliency (Luthans et al., 2008).

PsyCap refers to a person's positive psychological state of development. (1) self efficacy: having confidence to take on and put in the necessary effort to succeed at challenging tasks; (2) optimism: making a positive attribution about succeeding now and in the future; (3) hope: persevering towards goals and, (4) resiliency: when beset by problems and adversity, sustaining and bouncing back and even beyond to attain success (Luthans et al., 2007).

Research showed that individuals with the positive psychological capacities report higher self-efficacy, have optimistic expectation, and set higher goals for themselves. These four positive psychological resources could help individual thrive and succeed at work (Lyubomirsky et al., 2005).

The four PsyCap dimensions are conceptually independent (Luthans et al., 2007) and empirically valid (Bryant \& Cvengros, 2004).

\subsubsection{Hope}

The first construct of PsyCap is hope. It represents the motivational energy to identify the way to achieve career goals (Luthans et al., 2007). Individuals with greater hope, have more energy to pursue success (Snyder et al., 2000). Hope is a belief to determine significant purposes and a process by which individual overcomes obstacles (Çetin \& Basım, 2011).

Hope is associated with academic and athletic performance, mental and physical health, and ability to cope with adversity (Snyder, 2000). High-hope individuals tend to be independent thinkers (Luthans et al., 2007). High hope individuals use agentic (goal directed) thinking to move along a pathway and continuing to progress along (Snyder et al., 1998).

Hopeful individuals tend to take risks and look for alternative pathways when old ones are blocked (Snyder, 2002). They seem more prone to work on creative ideas for solving problems and they look at problems and opportunities from different angels (Zhou \& George, 2003). They tend to be creative and resourceful, even with tight budgets (Luthans et al., 2007).

Hope is a positive motivational state that is based on an interactively derived sense of successful (1) agency (goal directed energy) and (2) pathways (planning to meet goals)" (Snyder et al., 1996). Hope is a motivational state whereby two elements, agency (goal-directed determination) and pathways (or planning to achieve those goals), interact. Hope makes it possible to put up with barriers during goal attainment with the strength of motivation (Synder et al., 1991).

Hope possesses the willpower to perform creatively and explore multiple pathways to reach the goals (Larson \& Luthans, 2006), thus, increasing the cognitive efforts towards goal attainment (Snyder, 1994).

Hope refers to the individual's perceived capability to derive pathways to attain desired goals and to motivate oneself via agency thinking to use those pathways (Snyder et al., 2002). Hope consists of pathways thinking, agency thinking, and the union of these two pathways (Snyder et al., 2002). Pathway thinking refers to the perceived capability to conjure up plans or routes to reach a goal, and agency thinking refers to the ability to initiate and sustain action toward desired goal through motivation and determination (Snyder, 1994).

Hope is a multidimensional construct comprised of both an individual's determination to set for and maintain effort toward goals and that individual's ability to discern alternative courses of action to attain those goals (Snyder, 2000).

Hope is based on the interaction between three factors: goals, agency and pathways. People are driven to accomplish their goals by their sense of agency, which provides them with an internalized determination and willpower to invest the energy necessary to achieve their goals. Those with high hope are motivated by their sense of having the capability to develop ways to get the things they want, which provides them with the ability to generate alternative pathways towards the accomplishment of their goals if the original ones have been blocked. Although research on the positive impact of hope is well established in clinical, educational, and athletic applications, research on the relationship between hope and work outcomes is just emerging. However, results are promising (Luthans \& Youssef, 2004). 


\subsubsection{Resilience}

Resilience is the second construct of PsyCap. Facing the negative events, individual with higher levels of resilience could deal with setbacks smoothly (Tugade et al., 2004). Resilience helps the individual to overcome adversity and uncertainty to achieve success (Gooty et al., 2009; Luthans et al., 2006).

It refers to the capacity to bounce back from adversity, conflict, failure, or even positive events (Luthans et al., 2007).

Resilience helps individuals to become flexible and adapt themselves (Coutu, 2002). Resilient individuals tend to bounce back from setbacks and difficult situation (Tugade \& Fredrickson, 2004).

It is the capacity to bounce back from adversity, uncertainty, failure, or even positive but seemingly overwhelming changes such as increased responsibility. The three components of resiliency are: a staunch acceptance of reality; a deep belief, often reinforced by strongly held values, that life is meaningful; and an uncanny ability to improvise and adapt to significant change (Luthans \& Youssef, 2004).

Resilient belief that one has what it takes to succeed provides the necessary staying power in the face of repeated failures, setbacks, and skeptical or even critical social reactions that are inherently discouraging (Bandura \& Locke, 2003).

It is an ability to settle and deal with the circumstances when facing negative situations, risk or important changes (Luthans, 2002).

Resilient individuals possess a staunch acceptance of reality, a deep belief, often buttressed by strongly held values, that life is meaningful and an uncanny ability to improvise (Coutu, 2002).

Resiliency is often characterized by positive coping and adaptation in the face of significant adversity or risk (Masten \& Reed, 2002).

It is the positive PsyCap to rebound, to "bounce back" from adversity, uncertainty, conflict, failure or even positive change, progress and increased responsibility (Luthans, 2002).

Resilient individuals have the ability to positively cope and adapt during risk and adversity (Masten, 2001).

Resilient individuals are optimistic, energetic towards life, curious, and open to new experiences (Klohnen, 1996). These individuals are humorous (Masten, 1994), and use creative exploration (Cohler, 1987).

Resilient individuals elicit positive emotions in themselves as well as in others (Fredrickson, 2004) which may help them to create supportive environment that facilitates innovative behaviors. These individuals have to ability to positive adaptation and adjustment to change (Luthans et al., 2007).

Resilient leaders are likely to encourage themselves and even their subordinates to take risks and to exhibit innovative behaviors (Peterson et al., 2008).

\subsubsection{Optimism}

The third construct of PsyCap is optimism. With higher levels of optimism regarding the future and confidence in abilities to succeed in the current job will motivate individuals to take charge of their own career (Seligman, 1998).

It had a direct positive effect on creativity. Optimistic leaders pursue new and creative approaches towards problems solving (Peterson et al., 2008).

Optimism can easily facilitate adaptation to changing work context and past failures. Optimism as a facet of PsyCap is associated with a positive outlook but is not an unchecked process without realistic evaluation. Optimism is making an internal, relatively stable, and global attribution regarding positive events such as goal achievement, and an external, relatively unstable, and specific cause for negative events like a failed attempt at reaching a goal. Optimism is associated with a positive future outlook and a tendency to view positive events as within the control of self (Luthans et al., 2007).

It involves a positive explanatory style that attributes positive events to internal, permanent, and pervasive causes, and negative events to external, temporary, and situation specific ones. This allows individuals to take credit for favorable events in their lives, boosting their self-esteem and morale. Unlike hope, optimism has been applied not only to clinical applications, but also in organizational settings (Luthans \& Youssef, 2004). Optimism has been associated with the improvement of performance (Martin et al., 2003).

It is depicted in positive psychology as both a positive future expectation open to development (Carver \& Scheier, 2002). 
Optimists are people who make internal and stable attributions regarding positive events and attribute negative events to external, temporary, and situation-specific factors (Seligman, 1998). It is not based on an unchecked process that has no realistic assessment (Peterson, 2000).

Optimism means positive expectations about the future (Peterson et al., 2011). Optimism is generalized expectations that individual hopes for the best and persistence for achieving the target (Synder et al., 1991).

It requires objective assessments that a person follows to succeed (Luthans et al., 2008). Compared to pessimists, optimists benefit from career opportunities at a high level and pursue their aims under tough conditions (Wrosch et al., 2003).

Optimistic individuals relate negative events as external (not my fault), unstable (occurred this time only), and specific (this event only), while pessimists interpret the same events as internal, stable, and global (Peterson, 2000). Optimism has been supported as a state-like, malleable construct that is open to development (Schneider, 2001).

It is associated with a variety of individuals outcomes including depression, and mental health (Seligman, 1998) burnout and (Chang et al., 2000). Optimists tend to maintain positive expectations about the results (Avey et al., 2008). Optimistic individuals appraise daily hassles in a positive way by expecting gain or growth from such events (Fry, 1995). These individuals have the ability to cope with stress (Strutton \& Lumpkin, 1992). Optimists keep on working hard and coping actively with the problems they face while pursuing desirable outcomes. (Kluemper et al., 2009).

\subsubsection{Self-Efficacy}

Self-efficacy is one's confidence in his or her ability to mobilize the motivation, cognitive resources, and courses of action necessary to execute a specific course of action within a given context (Luthans \& Youssef, 2004).

Individuals with high self efficacy choose challenging tasks, develop complicated ways to overcome the obstacles (Keleş, 2011), and become persistent and success-oriented in terms of difficulties (Shahnawaz \& Jafri, 2009).

Self-efficacy represents individual confidences in one's ability to become successful (Gooty et al., 2009).

Efficacy has been shown to be related to the socialization and retention of new employees (Bauer et al., 2007) and the organizational commitment and turnover intentions of existing staff (Harris \& Cameron, 2005).

Self-efficacy had a strong positive relationship with work-related performance (Bandura \& Locke, 2003) even in the absence of feedback (Judge et al., 2007).

It was found to have a strong positive relationship with work-related performance (Bandura \& Locke, 2003).

Self-efficacy beliefs help to persevere in the face of obstacles and cope with distressing and self-debilitating emotional states that hinder the execution of activities (Bandura \& Locke, 2003). Efficacious individuals are inventive, resourceful (Bandura, 1986) as well as creative (Tierney \& Farmer, 2002).

It plays a critical role in important human performance determinants such as goals, aspirations, and the perceived opportunities of a given project (Bandura, 2000).

Displaced employees with high self-efficacy are confident that they possess the right skills and abilities to perform well in their future jobs and are confident of being reemployed (Lim \& Loo, 2003).

Self-efficacy is one's belief to perform the task successfully and fulfill motivational, cognitive and operational resources (Stajkovic \& Luthans, 1998).

Several approaches have been found successful in developing efficacy, including mastery experiences, modeling, social persuasion, and physiological/psychological arousal (Bandura, 1997).

These four dimensions are considered to meet the criteria for POB in that they are each positive, unique, developable, measurable and performance-related (Luthans \& Youssef, 2004). Confirmatory factor analyses have consistently demonstrated support for a core underlying factor whereby the shared variance or commonality between each facet comprises the higher order factor, PsyCap (Culbertson et al., 2010).

Individuals high on PsyCap are able to develop new path ways (hope) to attain their goals. These individuals possess the confidence (efficacy) necessary to arrive at desired goals through these alternative paths, have positive attribution and outlook for future (optimism) and are able to bounce back from setbacks (resilience) in case of any difficulty or failure that may arise due to implementing innovative ideas (Avey et al., 2008; Luthans et al., 2007). 
On the surface and as used in everyday language, hope, resiliency, optimism, and efficacy seem very similar and interchangeable. However, the positive psychology literature (Snyder \& Lopez, 2002) and POB (Luthans \& Youssef, 2007) has clearly differentiated these positive capacities and empirically based analyses have found discriminant validity among them (Bryant \& Cvengros, 2004; Luthans, 2007; Youssef \& Luthans, 2007).

\subsection{Job Embeddedness}

JE is a new concept for how well a person was socially enmeshed within their organization (Granovetter, 1985). It is relatively a new concept and is under-researched in the hospitality management and marketing literature (Karatepe \& Ngeche, 2011).

JE reflects employees' decisions to participate broadly and directly, and it moves scholarly attention beyond dissatisfaction-induced leaving. JE is a retention (or "antiwithdrawal") construct (Dong-Hwan \& Jung-Min, 2012).

It has been conceptualized to consist of two dimensions: on-the-job (organizational) embeddedness and off-the-job (community) embeddedness. On-the-JE refers to the degree to which individuals are immersed in their organizations, while off-the-JE represents the degree to which individuals are immersed in their communities. On-the-JE better predicts employee job performance than does the off-the-JE. Furthermore, the On-the-JE better predicts employee retention than does the off-the-JE. Each embeddedness dimension is composed of three facets: fit, links, and sacrifice (Allen, 2006; Ng \& Feldman, 2009).

JE encompasses the total forces on an individual that cause the person to remain at his/her current job. JE has been empirically demonstrated to impact work-related behaviors such as turnover, performance, absenteeism and citizenship behaviors (Lee et al., 2004; Ng \& Feldman, 2009).

JE is constellation of influences which enmesh or embed people within organizations. Consequently, the embedded employee either finds it more difficult to leave or does not want to leave the organization to which they have become a part (Mitchell et al., 2001).

$\mathrm{JE}$ is the combined material, financial, and psychological factors that keep a person from leaving his or her job (Mitchell et al., 2001). It is an employee retention theory and evolved from the unfolding model voluntary employee turnover (Lee et al., 1996).

\subsection{The Dimensions of Job Embeddness}

The three component dimensions of JE include links, fit and sacrifice (Mitchell et al., 2001).

\subsubsection{Fit}

Organizational fit is the degree of similarity or compatibility between the individual and organizational culture, overlap between the individual abilities and organizational demands, and match between individual interests and organizational rewards. Community fit is the degree of match, similarity, or compatibility between the individual and his or her community (Ng \& Feldman, 2009).

Fit is the individual's perceived compatibility with the organization and with the community (Felps et al., 2009).

It refers to the match between an employee's goals and values and those of the organization; higher fit indicates higher embeddedness (Holtom et al., 2006).

A person who perceives person-organization fit would find it difficult to leave an organization. People take jobs for other fit reasons, including proximity to extended family, climate considerations, and culture (Valle, 2006).

Fit is an employee's perceived compatibility or comfort with an organization and with his or her environment. Ensuring that individuals fit well within the organization's environment is one way for managers to reduce early turnover (Snow, 2002).

Fit to an organization is the degree perceived in how compatible an employee feels to the job he/she is performing and the company he/she belongs to. The more the individual feels fitted to the job, colleagues and the business culture, the lower turnover is (Mitchell et al., 2001).

It is an employee's perceived compatibility with his or her organization. This construct has been further described as a composite of person-organization fit (Chatman, 1989) and person-job fit (Careless, 2005). Studies have shown that poor person-organization fit leads to turnover (Villanova et al., 1994).

\subsubsection{Links}

Links means that each individual is linked to other people, teams, and organizations officially or unofficially (Dong-Hwan \& Jung-Min, 2011). 
Links refers to the formal or informal connections of individuals with other people, projects, locations, activities, and groups in their organizations and communities (Ng \& Feldman, 2009).

The more connected an individual and/or his or her family is with the organization and the community, the more difficult leaving is and the more embedded the person is (Felps et al., 2009).

The links aspect of embeddedness suggests that employees have formal and informal connections with other entities on the job and, as the number of those links increases, embeddedness is higher (Holtom et al., 2006).

Links are the formal or informal connections one has to other people in the organization, and includes non-work connections (Valle, 2006).

Links are characterized as formal or informal connections between a person, and institutions or other people (Lee et al., 2004). Links to the organization is how connected he/she is to other people, team or organizations. Links are the degree to which people have connections to other people and activities (Mitchell et al., 2001).

\subsubsection{Sacrifice}

Sacrifice refers to the ease with which the links can be broken upon quitting work or moving to another home or community (Ng \& Feldman, 2009).

Sacrifice refers to the perceived costs associated with leaving. These costs may be physical or psychological. Community sacrifices are applicable only if the person will move to a new location (Felps et al., 2009).

Sacrifice concerns the perceived costs of leaving the organization, both financial and social. The higher the perceived costs, the greater the embeddedness (Holtom et al., 2006).

Sacrifice is the individual's perceived cost (in psychological and financial terms) of job change. The psychological costs may include those associated with leaving friends or family and job conditions which one desires. Financial costs may include relocation related expenses (Fields et al., 2005).

Sacrifice means the opportunity cost of turnover, which is the perceived cost of physical or psychological convenience sacrificed when leaving a current job (Park \& Lee, 2004).

Sacrifice to the organization is the perceived cost of physical or psychological convenience sacrificed when leaving a current job. Sacrifice is the degree of difficulty it would require for a person to break the links; what they would forfeit if they left (Mitchell et al., 2001).

Sacrifice captures the perceived cost of material or psychological benefits that may be forfeited by leaving one's job (Taunton, 1997; Shaw et al., 1998).

\subsection{Organizational Cynicism}

There are different types of cynicism such as social cynicism, employee cynicism, civil servant cynicism, work cynicism and Organizational Cynicism (OC) (Dean et al., 1998).

General cynicism is an inborn and determined personality trait which reflects generally negative perceptions about human behavior. Cynicism is a defensive response, because it can shield employees against feeling strong emotions and prepare them for the next "inevitable failure" (Abraham, 2000).

Cynicism is an individual's having negative feelings, such as anger, disappointment, and hopelessness (Özler Ergun et al., 2010).

Cynicism is an evaluative judgment that stems from an individual's employment experiences (Bruch \& Vogel, 2006).

Cynicism can be expressed both overtly, such as through direct statements questioning the integrity of the organization, and covertly through the use of sarcastic humor and nonverbal behaviors, such as "knowing 1 looks," "rolling eyes," and "smirks" (Dean et al., 1998).

Cynicism is a negative and is therefore a sensitive topic to managers and organizations (Andersson, 1996).

Cynics may feel embarrassment, hatred and even dishonor when they think about their organizations. Business ethics is a system, principles, codes or values, which provide guidelines for morally right behavior and honesty in specific situations (Lewis 1985).

$\mathrm{OC}$ is an individual negative feelings, such as disturbance, dissatisfaction and hopelessness about the staff and organization (Ozler et al., 2011).

It is an attitude that involves unfriendliness oneself from the organization due to a confidence that the organization lacks honesty and will always attempt to fool its employees (Nair \& Kamalanabhan, 2010). 
OC exist as a resistance against improvement of the organization and severely damaging the organization (Arabac1, 2010).

OC concept is the negative attitudes of individual in connection with his/her organization and thought of organization deprives honesty and integrity (Kalağan, 2009).

It arises when employees believe that their organization is deficient in honesty. This may especially result from the perception of which basic expectations related to morality, justice and honesty are despoiled. OC is not simply the feelings that 'negative' people bring into the organization, but that these attitudes are shaped by experiences in the work context" (Johnson \& O'Leary-Kelly, 2003).

$\mathrm{OC}$ is an attitude, characterized by frustration and negatively valenced beliefs, resulting primarily from unmet expectations, which is capable of being directed towards an organization in general and/or more specific facets of the organizational environment (Brockway et al., 2002).

It refers to the lack, among workers, of the feelings of righteousness, confidence, fairness and sincerity towards the organization where they work (Abraham, 2000).

OC is a learned response rather than a personality-based predisposition (Wanous et al., 2000).

It is a negative attitude towards the organization where one works, which has cognitive, affective and behavioral dimensions (Dean et al., 1998).

OC was found to have negative relationships with organizational commitment, organizational citizenship behavior, and job satisfaction (Andersson \& Bateman, 1997).

It is a negative attitude that develops as a result of perceived malfeasance of the agent or entity (Reicher et al., 1997). OC is a general and specific attitude characterized with anger, hopelessness, disappointment and a tendency to distrust individuals, groups, ideologies, social abilities or institutions (Andersson, 1996).

\subsection{Organizational Cynicism Dimensions}

$\mathrm{OC}$ is a negative attitude with three dimensions towards the organization where one works. These dimensions are (1) a belief that the organization lacks integrity; (2) negative affect toward the organization; and (3) tendencies to disparaging and critical behaviors toward the organization (Kutanis \& Çetinel, 2009).

It is a complex process which culminates in a belief that the organization is not fair, in loss of confidence in the organization, and thus in an increase in negative behaviors towards the organization (Dean et al., 1998).

\subsubsection{Cognitive Dimension}

The first dimension of OC is the belief in the organization's lack of honesty. The cognitive (belief) dimension consists of the belief that the organization's practices are deficient in justice, honesty and sincerity (Dean et al., 1998). Cognitive dimension refers to employees' disbelief in their organizations. They believe that the practices and behaviors in the organization lack certain values such as fairness and sincerity (Urbany, 2005). Due to these beliefs, they think that the organizational practices betray them (Dean et al., 1998).

\subsubsection{Emotional Dimension}

Emotional /sentimental reactions to the organization are the second dimension of OC. The sensitive/emotional dimension of OC consists of strong emotional reactions towards the organization. These strong reactions can be exemplified; cynics may feel disrespect and anger towards their organizations; or feel discomfort, hatred and even shame when they think about their organizations (Dean et al., 1998).

Emotional dimension consists of emotional reactions such as anxiety, shame, anger, disappointment (O'Leary, 2002) or rage/pessimism (Brandes, 1999). OCs of emotional dimension contains some powerful emotional reactions like disrespect, anger, boredom and shame (Abraham, 2000).

\subsubsection{Behavioral Dimension}

The last dimension refers to negative tendencies and mainly humiliating attitudes. Behavioral dimension, the last dimension of OC, consists of negative and frequently critical attitudes. The most prominent of behavioral tendencies is strong critical expressions towards the organization. These may occur in various forms. The most obvious one is the expressions about the organization asserting that it lacks critical notions like honesty and sincerity (Dean et al., 1998).

Behavioral dimension covers employees' fierce criticisms of the organization such as condescension, denigration and belittlement (Turner \& Valentine, 2001). In this dimension, the employee may get alienated from or sever her ties with the organization (O'Brien et al., 2004). 


\section{Research Model}

The proposed comprehensive conceptual model is presented in Figure 1. The diagram below shows that there is one independent variable of PsyCap. There are two dependent variables of JE and OC. It shows the rational link among the variables. From the above discussion, the research model is as shown in Figure 1 below.

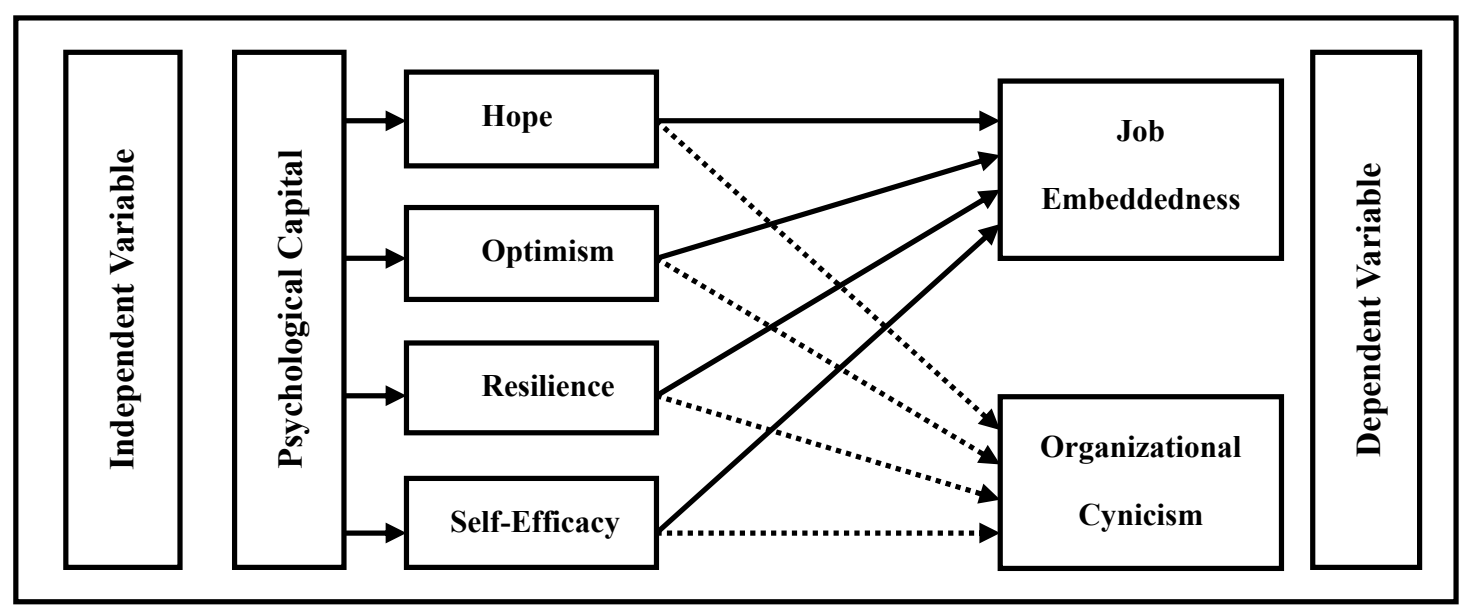

Figure 1. Proposed comprehensive conceptual model

The research framework suggests that PsyCap have an impact on JE and OC. PsyCap as measured consists of hope, optimism, resilience and self-efficacy (Luthans, 2006). JE is measured in terms of fit, links, and sacrifice (Nitchell et al., 2001). OC is measured in terms of belief, affect and behavior (Reichers \& Wanous, 1997).

\section{Research Questions and Hypotheses}

The research process includes both questions and hypotheses. The research questions of this study are as follows:

Q1: What is the nature and the extent of the relationship between PsyCap (Hope) and JE at Menoufia University Hospitals.

Q2: What is the nature of the relationship between PsyCap (Optimism) and JE at Menoufia University Hospitals.

Q3: What is the extent of the relationship between PsyCap (Resilience) and JE at Menoufia University Hospitals.

Q4: What is the statistically significant relationship between PsyCap (Self-Efficacy) and JE at Menoufia University Hospitals.

Q5: What is the nature and the extent of the relationship between PsyCap (Hope) and OC at Menoufia University Hospitals.

Q6: What is the nature of the relationship between PsyCap (Optimism) and OC at Menoufia University Hospitals.

Q7: What is the extent of the relationship between PsyCap (Resilience) and OC at Menoufia University Hospitals.

Q8: What is the statistically significant relationship between PsyCap (Self-Efficacy) and OC at Menoufia University Hospitals.

The following hypotheses were developed to test if there is a significant correlation between PsyCap, JE and OC.

H1: Employees' PsyCap (Hope) has no significant effect on JE at Menoufia University Hospitals.

H2: Employees' PsyCap (Optimism) has no significant impact on JE at Menoufia University Hospitals.

H3: Employees' PsyCap (Resiliency) has no significant influence on JE at Menoufia University Hospitals.

H4: Employees' PsyCap (Self-Efficacy) has no relationship with JE at Menoufia University Hospitals.

H5: Employees' PsyCap (Hope) has no significant effect on OC at Menoufia University Hospitals.

H6: Employees' PsyCap (Optimism) has no significant impact on OC at Menoufia University Hospitals.

H7: Employees' PsyCap (Resiliency) has no significant influence on OC at Menoufia University Hospitals

H8: Employees' PsyCap (Self-Efficacy) has no relationship with OC at Menoufia University Hospitals. 


\section{Research Methods}

\subsection{Population and Sample}

The study subjects are employees at Menoufia University Hospitals in Egypt, including, physicians, nurses and administrative staff. The total population is 2839 employees. Determination of sample size was calculated using the formula (Daniel, 1999) as follows:

$$
\mathrm{n}=\frac{N \times(Z)^{2} \times P(1-P)}{d^{2}(N-1)+(Z)^{2} \times P(1-P)}
$$

The number of samples obtained by 382 employees at Menoufia University Hospitals is presented in Table 1.

Table 1. Distribution of the sample size

\begin{tabular}{llll}
\hline Job Category & Number & Percentage & Size of Sample \\
\hline Physicians & 486 & $17.1 \%$ & $338 \times 17.1 \%=134$ \\
Nurses & 1675 & $59.0 \%$ & $338 \times 59.0 \%=189$ \\
Administrative Staff & 678 & $23.9 \%$ & $338 \times 23.9 \%=34$ \\
Total & $\mathbf{2 8 3 9}$ & $\mathbf{1 0 0 \%}$ & $\mathbf{3 3 8}$ X 100\% $=\mathbf{3 3 8}$ \\
\hline
\end{tabular}

Source: Personnel Department at Menoufia University, 2014.

\subsection{Method of Data Collection}

The goal of this study was to examine the relationships between PsyCap, JE and OC at Menoufia University Hospitals. A survey research method was used to collect data in this study. The questionnaire included four questions, relating to PsyCap, JE, OC and biographical information of employees at Menoufia University Hospitals.

A total of 338 questionnaires were sent out in January, 2014 and collected in March 2014. Three hundred and twenty five effective questionnaires were collected $(96 \%$ collection rate). Ten ineffective ones (with unanswered questions, duplicated entries and inappropriate marks) were excluded, and the number of effective ones was 315 ( $93 \%$ valid collection rate). The sample distribution is listed in Table 2.

Table 2. Characteristics of items of the sample

\begin{tabular}{|c|c|c|c|}
\hline Variables & & Number & Percentage \\
\hline \multirow{4}{*}{ 1- Job Title } & Physicians & 131 & $41.6 \%$ \\
\hline & Nurses & 160 & $50.8 \%$ \\
\hline & Administrative Staff & 24 & $7.6 \%$ \\
\hline & Total & 315 & $100 \%$ \\
\hline \multirow{3}{*}{ 2- Sex } & Male & 123 & $39.0 \%$ \\
\hline & Female & 192 & $61.0 \%$ \\
\hline & Total & 315 & $100 \%$ \\
\hline \multirow{3}{*}{ 3- Marital Status } & Single & 90 & $28.6 \%$ \\
\hline & Married & 225 & $71.4 \%$ \\
\hline & Total & 315 & $100 \%$ \\
\hline \multirow{4}{*}{ 4- Age } & Under 30 & 128 & $40.6 \%$ \\
\hline & From 30 to 45 & 127 & $40.3 \%$ \\
\hline & Above 45 & 60 & $19.0 \%$ \\
\hline & Total & 315 & $100 \%$ \\
\hline \multirow{4}{*}{ 5- Educational Level } & Secondary School & 108 & $34.3 \%$ \\
\hline & University & 150 & $47.6 \%$ \\
\hline & Post Graduate & 57 & $18.1 \%$ \\
\hline & Total & 315 & $100 \%$ \\
\hline \multirow{4}{*}{ 6- Period of Experience } & Less than 5 years & 102 & $32.4 \%$ \\
\hline & From 5 to 10 & 82 & $26.0 \%$ \\
\hline & More than 10 & 131 & $41.6 \%$ \\
\hline & Total & 315 & $100 \%$ \\
\hline
\end{tabular}




\subsection{Research Variables and Methods of Measuring}

The 24-item scale PsyCap section is based on Luthans, 2006. There were six items measuring hope, six items measuring optimism, six items measuring resilience, and six items measuring self-efficacy.

The 18-item scale JE section is based on Nitchell et al., 2001. There were six items measuring fit, six items measuring links, and six items measuring sacrifice.

The 18-item scale OC section is based on Reichers \& Wanous, 1997. There were six items measuring belief, six items measuring affect, and six items measuring behavior.

Responses to all items scales were anchored on a five (5) point Likert scale for each statement which ranges from (5) "full agreement," (4) for "agree," (3) for "neutral," (2) for "disagree," and (1) for "full disagreement."

\subsection{Methods of Data Analysis and Testing Hypotheses}

The researcher has employed the following methods: (1) The Alpha Correlation Coefficient (ACC), (2) Multiple Regression Analysis (MRA), and (3) the statistical testing of hypotheses which includes F- test and T-test. They are found in SPSS.

\section{Hypotheses Testing}

Before testing the hypotheses and research questions, descriptive statistics were performed to find out means and standard deviations of PsyCap, JE and OC.

Table 3. The mean and standard deviations of PsyCap, JE and OC

\begin{tabular}{llll}
\hline Variables & The Dimension & Mean & Standard Deviation \\
\hline \multirow{4}{*}{ PsyCap } & Hope & 3.2995 & 1.16367 \\
& Optimism & 3.2323 & 1.01297 \\
& Resilience & 3.4429 & 0.98057 \\
& Self-Efficacy & 3.5979 & 0.97129 \\
& Total Measurement & $\mathbf{3 . 3 9 3 1}$ & $\mathbf{0 . 9 8 8 6 3}$ \\
\hline \multirow{3}{*}{$\mathbf{E}$} & Fit & 3.7598 & 1.22639 \\
& Links & 3.6772 & 1.30858 \\
& Sacrifice & 3.6624 & 1.26643 \\
& Total Measurement & $\mathbf{2 . 7 7 4 9}$ & $\mathbf{0 . 9 3 5 0 6}$ \\
\hline \multirow{3}{*}{ OC } & The Belief Dimension & 3.5942 & 0.90349 \\
& The Affective Dimension & 3.4354 & 1.07193 \\
& The Behavioral Dimension & 3.5963 & 1.04705 \\
& Total Measurement & $\mathbf{2 . 6 5 6 5}$ & $\mathbf{0 . 7 0 8 2 1}$ \\
\hline
\end{tabular}

Table 3 lists the mean and standard deviation among variables. The mean of each variable is more than 3 , and this result indicates that the study subjects in general have a higher level of PsyCap, JE and OC.

The different facets of PsyCap (hope, optimism, resilience and self-efficacy) are examined. Most respondents identified the presence of self-efficacy $(\mathrm{M}=3.59, \mathrm{SD}=0.971)$. This was followed by resilience $(\mathrm{M}=3.44$, $\mathrm{SD}=0.980)$, hope $(\mathrm{M}=3.29, \mathrm{SD}=1.163)$, and optimism $(\mathrm{M}=3.23, \mathrm{SD}=1.012)$.

The different facets of JE (fit, links, and sacrifice) are examined. Most respondents identified the presence of fit $(\mathrm{M}=3.75, \mathrm{SD}=1.226)$. This was followed by links $(\mathrm{M}=3.67, \mathrm{SD}=1.308)$ and sacrifice $(\mathrm{M}=3.66, \mathrm{SD}=1.266)$.

The different facets of OC (belief, affect and behavior) are examined. Most respondents identified the presence of behavioral dimension $(\mathrm{M}=3.596, \mathrm{SD}=1.047)$. This was followed by belief dimension $(\mathrm{M}=3.594, \mathrm{SD}=0.903)$, and affective dimension $(\mathrm{M}=3.43, \mathrm{SD}=1.071)$.

\subsection{Evaluating Reliability}

ACC was used to evaluate the degree of internal consistency among the contents of the scale under testing. Table 4 shows the results of the reliability test for each variable of PsyCap, JE and OC.

ACC was decided to exclude variables that had a correlation coefficient of less than 0.30 when the acceptable limits of ACC range from 0.60 to 0.80 , in accordance with levels of reliability analysis in social sciences (Nunnally \& Bernstein, 1994). 
Table 4. Reliability of PsyCap, JE and OC

\begin{tabular}{llll}
\hline Variables & The Dimension & Number of Statement & ACC \\
\hline \multirow{4}{*}{ PsyCap } & Hope & 6 & 0.8877 \\
& Optimism & 6 & 0.7944 \\
& Resilience & 6 & 0.7966 \\
& Self-Efficacy & 6 & 0.7750 \\
& Total Measurement & $\mathbf{2 4}$ & $\mathbf{0 . 9 5 3 0}$ \\
\hline \multirow{3}{*}{ Fit } & Links & 6 & 0.9698 \\
& Sacrifice & 6 & 0.9594 \\
& Total Measurement & 6 & 0.9613 \\
OC & The Belief Dimension & $\mathbf{1 8}$ & $\mathbf{0 . 9 8 6 9}$ \\
\hline & The Affective Dimension & 6 & 0.9054 \\
& The Behavioral Dimension & 6 & 0.9411 \\
& Total Measurement & 6 & 0.9080 \\
\hline
\end{tabular}

To assess the reliability of the data, Cronbach's alpha test was conducted. Table 4 shows the reliability results for PsyCap, JE and OC. All items had alphas above 0.60 and were therefore excellent, according to Langdridge's (2004) criteria.

The 24 items of PsyCap are reliable because the ACC is 0.9530 . The six items of hope scales are reliable due to the fact that the ACC is 0.8877 . The optimism, which consists of six items, is reliable since the ACC is 0.7944 . The six items related to resilience are reliable as ACC is 0.7966 . Furthermore, the self-efficacy, which consists of six items, is reliable due to the fact that the ACC is 0.7750 .

The 18 items of JE are reliable due to the fact that the ACC is 0.9869 . The fit, which consists of six items, is reliable since the ACC is 0.9698 while the six items related to links is reliable as the ACC is 0.9594 . Furthermore, the sacrifice, which consists of six items, is reliable due to the fact that the ACC is 0.9613 .

The 18 items of OC are reliable because the ACC is 0.9645 . The six items of belief scales are reliable due to the fact that the ACC is 0.9054 . The affect, which consists of six items, is reliable since the ACC is 0.9411 . The six items related to behavior are reliable as ACC is 0.9080 .

\subsection{The Correlation among the Research Variables}

Table 5. Descriptive statistics and correlation matrix for all variables

\begin{tabular}{llllll}
\hline Variables & Mean & Std. Deviation & PsyCap & JE & OC \\
\hline $\begin{array}{l}\text { Psychological } \\
\text { Capital }\end{array}$ & 3.39 & 0.988 & 1.000 & & \\
Job & 2.77 & 0.935 & $0.443^{* *}$ & 1.000 & \\
Embeddedness & 2.65 & 0.708 & $-0.531^{* *}$ & $-0.390^{* *}$ & 1.000 \\
\hline Organizational Cynicism & & & \\
\hline
\end{tabular}

Table 5 shows correlation coefficients between the research variables, and results indicate the presence of significant correlation between variables (PsyCap, JE, and OC).

The level of PsyCap of employees is average (Mean=3.39; $\mathrm{SD}=0.988$ ), while JE is lower (Mean=2.77; SD 0.935) which led to cynicism toward the organization (Mean=2.65; SD. 0.708).

Table (5) reveals the existence of a positive correlation between PsyCap and JE $(\mathrm{R}=0.443 ; \mathrm{P}<0.01)$, which means that the high level of PsyCap leads to higher JE.

The table shows the existence of a reverse correlation between JE and OC $(\mathrm{R}=-0.390 ; \mathrm{P}<0.01)$ and this shows that the high level of JE contributes to mitigation of feelings of OC of employees.

Finally, Table (5) refers to the existence of reverse correlation between the PsyCap and $\mathrm{OC}(\mathrm{R}=-0.531 ; \mathrm{P}<0.01)$ implying that the high level of PsyCap reduces feelings of OC of employees. 


\subsection{The Relationship between PsyCap (Hope) and JE}

Table 6. MRA results for PsyCap (Hope) and JE

\begin{tabular}{llll}
\hline The Variables of PsyCap (Hope) & Beta & $\mathrm{R}$ & $\mathrm{R}^{2}$ \\
\hline 1. $\quad$ When I find myself under pressure, I think how to get out of this predicament. & 0.169 & 0.337 & 0.113 \\
2. I have a strong will to achieve my goals. & 0.048 & 0.299 & 0.089 \\
3. I have several alternatives to resolve any problem I may face. & $0.286^{* *}$ & 0.228 & 0.052 \\
4. I feel that I have achieved great success in my career. & $0.293^{* *}$ & 0.322 & 0.103 \\
5. I can think of more than one way to achieve my goals. & $0.255^{*}$ & 0.397 & 0.157 \\
6. I have achieved most of goals I have perused. & 0.028 & 0.384 & 0.147 \\
- $\quad$ Multiple Correlation Coefficients (MCC) & 0.461 & \\
- Determination of Coefficient (DF) & 0.212 & \\
- The Value of Calculated F & 13.842 & \\
- Degree of Freedom & 6,308 & \\
- $\quad$ The Value of Indexed F & 2.80 & \\
- Level of Significance & 0.01 & \\
\hline P & & & \\
\end{tabular}

According to Table 6, the regression-coefficient between PsyCap (Hope) and JE is $\mathrm{R}=0.461$ and $\mathrm{R}^{2}=0.212$. This means that the JE can be explained by the dimensions of PsyCap, for example, "I can think of more than one way to achieve my goals" $\left(\beta=0.255, \mathrm{R}=0.397\right.$, and $\left.\mathrm{R}^{2}=0.157\right)$, "I have achieved most of goals I have perused" $\left(\beta=0.028, R=0.384\right.$, and $R^{2}=0.147$ ), and "when I find myself under pressure, I think how to get out of this predicament." ( $\beta=0.169, R=0.337$, and $\left.R^{2}=0.113\right)$. Because of the calculated $F(13.842)$ more than indexed $F$ (2.80) at the statistical significance level of 0.01 , the null hypothesis is rejected.

\subsection{The Relationship between PsyCap (Optimism) and JE}

Table 7. The relationship between PsyCap (Optimism) and JE

\begin{tabular}{|c|c|c|c|}
\hline The Variables of PsyCap (Optimism) & Beta & $\mathrm{R}$ & $\mathrm{R}^{2}$ \\
\hline 1. When I'm not sure of something, usually I expect the best. & 0.061 & 0.193 & 0.037 \\
\hline 2. I can easily feel relaxed. & 0.100 & 0.332 & 0.110 \\
\hline 3. When I feel indignant on the performance of the work, I delay it for another time. & 0.110 & 0.208 & 0.043 \\
\hline 4. I am always optimistic about my future. & 0.067 & 0.322 & 0.103 \\
\hline 5. I expect events to ensure continuity in achieving my goals. & 0.097 & 0.397 & 0.157 \\
\hline 6. I expect pleasant events, rather than unpleasant events. & 0.180 & 0.384 & 0.147 \\
\hline - $\quad$ Multiple Correlation Coefficients (MCC) & 0.444 & & \\
\hline - $\quad$ Determination of Coefficient (DF) & 0.197 & & \\
\hline - $\quad$ The Value of Calculated $F$ & 12.617 & & \\
\hline - $\quad$ Degree of Freedom & 6,308 & & \\
\hline - $\quad$ The Value of Indexed F & 2.80 & & \\
\hline - $\quad$ Level of Significance & 0.01 & & \\
\hline
\end{tabular}

According to Table 7, the regression-coefficient between PsyCap (Optimism) and JE is $\mathrm{R}=0.444$ and $\mathrm{R}^{2}=0.197$. This means that the JE can be explained by the dimensions of PsyCap, for example, "I expect events to ensure continuity in achieving my goals" $\left(\beta=0.097, \mathrm{R}=0.397\right.$, and $\left.\mathrm{R}^{2}=0.157\right)$, "I expect pleasant events, rather than unpleasant events" $\left(\beta=0.180, R=0.384\right.$, and $\left.\mathrm{R}^{2}=0.147\right)$, and "I am always optimistic about my future" ( $\beta=$ $0.067, \mathrm{R}=0.322$, and $\mathrm{R}^{2}=0.103$ ). Thus, the null hypothesis is rejected because PsyCap (Optimism) and JE have a statistical relationship at the significance level of 0.01 .

\subsection{The Relationship between PsyCap (Resilience) and JE}

According to Table 8, the regression-coefficient between PsyCap (Resilience) and JE is $\mathrm{R}=0.444$ and $\mathrm{R}^{2}=0.197$. This means that the JE can be explained by the dimensions of PsyCap, for example, "I prefer work that is both new and challenging" $\left(\beta=0.513, \mathrm{R}=0.384\right.$, and $\left.\mathrm{R}^{2}=0.147\right)$, "I enjoy dealing with new and unusual events" ( $\beta=$ $0.101, R=0.324$, and $\left.R^{2}=0.104\right)$, and "I prefer following more than one route to achieve goals" $(\beta=0.115, R=$ 0.322 , and $\mathrm{R}^{2}=0.103$ ). Therefore, there is enough empirical evidence to reject the null hypothesis. 
Table 8. The relationship between PsyCap (Resilience) and JE

\begin{tabular}{llll}
\hline The Variables of PsyCap (Resilience) & Beta & $\mathrm{R}$ & $\mathrm{R}^{2}$ \\
\hline 1. I restore my normal mood quickly after unpleasant events. & $0.199^{* *}$ & 0.175 & 0.030 \\
2. I enjoy dealing with new and unusual events. & 0.101 & 0.324 & 0.104 \\
3. I usually succeed to form positive impression about others. & $0.110^{*}$ & 0.218 & 0.047 \\
4. I prefer following more than one route to achieve goals. & 0.115 & 0.322 & 0.103 \\
5. I prefer work that is both new and challenging. & $0.513^{* *}$ & 0.384 & 0.147 \\
6. I overcome feelings of anger that may possess me toward a particular person. & 0.182 & 0.302 & 0.091 \\
- $\quad$ Multiple Correlation Coefficients (MCC) & 0.444 & \\
- Determination of Coefficient (DF) & 0.197 & \\
- The Value of Calculated F & 12.577 & \\
- Degree of Freedom & 6,308 & \\
- $\quad$ The Value of Indexed F & 2.80 & \\
- Level of Significance & 0.01 & \\
\hline
\end{tabular}

$* \mathrm{P}<.05, * * \mathrm{P}<.01$

\subsection{The Relationship between PsyCap (Self-Efficacy) and JE}

Table 9. The relationship between PsyCap (Self-Efficacy) and JE

\begin{tabular}{|c|c|c|c|}
\hline The Variables of PsyCap (Self-Efficacy) & Beta & $\mathrm{R}$ & $\mathrm{R}^{2}$ \\
\hline 1. I enjoy a great deal of self-confidence. & $0.220^{*}$ & 0.235 & 0.055 \\
\hline 2. I'm in the best mood, when I'm actually in a situation of challenge. & 0.114 & 0.217 & 0.047 \\
\hline 3. I face many problems and I could solve them. & $0.141^{*}$ & 0.208 & 0.043 \\
\hline 4. I prefer self-reliance to find a solution when things go wrong. & 0.080 & 0.322 & 0.103 \\
\hline 5. I think that I have a very good chance to realize my goals in life. & 0.148 & 0.397 & 0.157 \\
\hline 6. I finish my work on time and do not wait until the last minute. & 0.171 & 0.384 & 0.147 \\
\hline - $\quad$ Multiple Correlation Coefficients (MCC) & 0.454 & & \\
\hline - $\quad$ Determination of Coefficient (DF) & 0.206 & & \\
\hline - $\quad$ The Value of Calculated F & 13.350 & & \\
\hline - $\quad$ Degree of Freedom & 6,308 & & \\
\hline - $\quad$ The Value of Indexed F & 2.80 & & \\
\hline - $\quad$ Level of Significance & 0.01 & & \\
\hline
\end{tabular}

According to Table 9, the regression-coefficient between PsyCap (Self-Efficacy) and JE is $R=0.454$ and $\mathrm{R}^{2}=$ 0.206. This means that the JE can be explained by the dimensions of PsyCap, for example, "I think that I have a very good chance to realize my goals in life" $\left(\beta=0.148, R=0.397\right.$, and $\left.R^{2}=0.157\right)$, "I finish my work on time and do not wait until the last minute" $\left(\beta=0.171, \mathrm{R}=0.384\right.$, and $\left.\mathrm{R}^{2}=0.147\right)$, and "I prefer self-reliance to find a solution when things go wrong" $\left(\beta=0.080, R=0.322\right.$, and $\left.R^{2}=0.103\right)$. Thus, the null hypothesis is rejected because PsyCap (Self-Efficacy) and JE have a statistical relationship at the significance level of 0.01 .

\subsection{The Relationship between PsyCap (Hope) and OC}

According to Table (10), the regression-coefficient between PsyCap (Hope) and OC is $\mathrm{R}=0.669$ and $\mathrm{R}^{2}=0.447$. This means that the OC can be explained by the dimensions of PsyCap, for example, "I can think of more than one way to achieve my goals" $\left(\beta=0.563, \mathrm{R}=0.537\right.$, and $\left.\mathrm{R}^{2}=0.288\right)$, "I feel that I have achieved great success in my career" ( $\beta=0.406, R=0.463$, and $\left.R^{2}=0.214\right)$, and "I have achieved most of goals I have perused" $(\beta=0.146$, $\mathrm{R}=0.418$, and $\left.\mathrm{R}^{2}=0.174\right)$. Because of the calculated $\mathrm{F}(41.484)$ more than indexed $\mathrm{F}(2.80)$ at the statistical significance level of 0.01 , the null hypothesis is rejected. 
Table 10. MRA results for PsyCap (Hope) and OC

\begin{tabular}{|c|c|c|c|}
\hline The Variables of PsyCap (Hope) & Beta & $\mathrm{R}$ & $\mathrm{R}^{2}$ \\
\hline 1. When I find myself under pressure, I think how to get out of this predicament. & $0.791^{* *}$ & -0.123 & 0.015 \\
\hline 2. I have a strong will to achieve my goals. & $-0.472^{* *}$ & -0.162 & 0.026 \\
\hline 3. I have several alternatives to resolve any problem I may face. & -0.092 & -0.413 & 0.170 \\
\hline 4. I feel that I have achieved great success in my career. & $-0.406^{* *}$ & -0.463 & 0.214 \\
\hline 5. I can think of more than one way to achieve my goals. & $-0.563^{* *}$ & -0.537 & 0.288 \\
\hline 6. I have achieved most of goals I have perused. & 0.146 & -0.418 & 0.174 \\
\hline - $\quad$ Multiple Correlation Coefficients (MCC) & 0.669 & & \\
\hline - $\quad$ Determination of Coefficient (DF) & 0.447 & & \\
\hline - The Value of Calculated F & 41.484 & & \\
\hline - $\quad$ Degree of Freedom & 6,308 & & \\
\hline - $\quad$ The Value of Indexed F & 2.80 & & \\
\hline - $\quad$ Level of Significance & 0.01 & & \\
\hline
\end{tabular}

6.8 The Relationship between PsyCap (Optimism) and OC

Table 11. The relationship between PsyCap (Optimism) and OC

\begin{tabular}{|c|c|c|c|}
\hline The Variables of PsyCap (Optimism) & Beta & $\mathrm{R}$ & $\mathrm{R}^{2}$ \\
\hline 1. When I'm not sure of something, usually I expect the best. & $-0.247^{* *}$ & -0.435 & 0.414 \\
\hline 2. I can easily feel relaxed. & 0.091 & -0.318 & 0.101 \\
\hline 3. When I feel indignant on the performance of the work, I delay it for another time. & $-0.101^{*}$ & -0.202 & 0.041 \\
\hline 4. I am always optimistic about my future. & $-0.216^{* *}$ & -0.463 & 0.214 \\
\hline 5. I expect events to ensure continuity in achieving my goals. & $-0.700^{* *}$ & -0.537 & 0.288 \\
\hline 6. I expect pleasant events, rather than unpleasant events. & $0.384^{* *}$ & -0.418 & 0.174 \\
\hline - $\quad$ Multiple Correlation Coefficients (MCC) & 0.644 & & \\
\hline - $\quad$ Determination of Coefficient (DF) & 0.415 & & \\
\hline - The Value of Calculated F & 36.428 & & \\
\hline - $\quad$ Degree of Freedom & 6,308 & & \\
\hline - $\quad$ The Value of Indexed F & 2.80 & & \\
\hline - $\quad$ Level of Significance & 0.01 & & \\
\hline
\end{tabular}

According to Table 11, the regression-coefficient between PsyCap (Optimism) and OC is $\mathrm{R}=0.644$ and $\mathrm{R}^{2}=$ 0.415 . This means that the $\mathrm{OC}$ can be explained by the dimensions of PsyCap, for example, "when I'm not sure of something, usually I expect the best" $\left(\beta=0.247, R=0.435\right.$, and $\left.\mathrm{R}^{2}=0.414\right)$, "I expect events to ensure continuity in achieving my goals" $\left(\beta=0.700, \mathrm{R}=0.537\right.$, and $\left.\mathrm{R}^{2}=0.288\right)$, and "I am always optimistic about my future" $\left(\beta=0.216, R=0.463\right.$, and $\left.R^{2}=0.214\right)$. Thus, the null hypothesis is rejected because PsyCap (Optimism) and OC have a statistical relationship at the significance level of 0.01 .

\subsection{The Relationship between PsyCap (Resilience) and OC}

According to Table 12, the regression-coefficient between PsyCap (Resilience) and OC is $\mathrm{R}=0.690$ and $\mathrm{R}^{2}=$ 0.476. This means that the OC can be explained by the dimensions of PsyCap, for example, "I prefer following more than one route to achieve goals" $\left(\beta=0.693, \mathrm{R}=0.487\right.$, and $\left.\mathrm{R}^{2}=0.237\right)$, and "I restore my normal mood quickly after unpleasant events" $\left(\beta=0.195, \mathrm{R}=0.413\right.$, and $\left.\mathrm{R}^{2}=0.170\right)$. Therefore, there is enough empirical evidence to reject the null hypothesis. 
Table 12. The relationship between PsyCap (Resilience) and OC

\begin{tabular}{|c|c|c|c|}
\hline The Variables of PsyCap (Resilience) & Beta & $\mathrm{R}$ & $\mathrm{R}^{2}$ \\
\hline 1. I restore my normal mood quickly after unpleasant events. & $-0.195^{* *}$ & -0.413 & 0.170 \\
\hline 2. I enjoy dealing with new and unusual events. & $-0.557^{* *}$ & -0.310 & 0.096 \\
\hline 3. I usually succeed to form positive impression about others. & $-0.230^{* *}$ & -0.210 & 0.044 \\
\hline 4. I prefer following more than one route to achieve goals. & $-0.693^{* *}$ & -0.487 & 0.237 \\
\hline 5. I prefer work that is both new and challenging. & $0.270^{*}$ & -0.283 & 0.080 \\
\hline 6. I overcome feelings of anger that may possess me toward a particular person. & $0.610^{* *}$ & -0.142 & 0.020 \\
\hline - $\quad$ Multiple Correlation Coefficients (MCC) & 0.690 & & \\
\hline - $\quad$ Determination of Coefficient (DF) & 0.476 & & \\
\hline - $\quad$ The Value of Calculated F & 46.683 & & \\
\hline - $\quad$ Degree of Freedom & 6,308 & & \\
\hline - $\quad$ The Value of Indexed F & 2.80 & & \\
\hline - $\quad$ Level of Significance & 0.01 & & \\
\hline
\end{tabular}

\subsection{The Relationship between PsyCap (Self-Efficacy) and OC}

Table 13. The relationship between PsyCap (Self-Efficacy) and OC

\begin{tabular}{|c|c|c|c|}
\hline The Variables of PsyCap (Self-Efficacy) & Beta & $\mathrm{R}$ & $\mathrm{R}^{2}$ \\
\hline 1. I enjoy a great deal of self-confidence. & -0.115 & -0.395 & 0.156 \\
\hline 2. I'm in the best mood, when I'm actually in a situation of challenge. & -0.121 & -0.416 & 0.173 \\
\hline 3. I face many problems and I could solve them. & -0.057 & -0.202 & 0.040 \\
\hline 4. I prefer self-reliance to find a solution when things go wrong. & $-0.174^{* *}$ & -0.463 & 0.214 \\
\hline 5. I think that I have a very good chance to realize my goals in life. & $-0.623^{* *}$ & -0.537 & 0.288 \\
\hline 6. I finish my work on time and do not wait until the last minute. & $0.295^{* *}$ & -0.418 & 0.174 \\
\hline - $\quad$ Multiple Correlation Coefficients (MCC) & 0.632 & & \\
\hline - $\quad$ Determination of Coefficient (DF) & 0.399 & & \\
\hline - $\quad$ The Value of Calculated $F$ & 34.137 & & \\
\hline - $\quad$ Degree of Freedom & 6,308 & & \\
\hline - $\quad$ The Value of Indexed F & 2.80 & & \\
\hline - $\quad$ Level of Significance & 0.01 & & \\
\hline
\end{tabular}

According to Table 13, the regression-coefficient between PsyCap (Self-Efficacy) and OC is $\mathrm{R}=0.632$ and $\mathrm{R}^{2}=$ 0.399. This means that the OC can be explained by the dimensions of PsyCap, for example, "I think that I have a very good chance to realize my goals in life" $\left(\beta=0.623, \mathrm{R}=0.537\right.$, and $\left.\mathrm{R}^{2}=0.288\right)$, "I prefer self-reliance to find a solution when things go wrong" $\left(\beta=0.174, \mathrm{R}=0.463\right.$, and $\left.\mathrm{R}^{2}=0.214\right)$, and "t I finish my work on time and do not wait until the last minute" $\left(\beta=0.295, \mathrm{R}=0.418\right.$, and $\left.\mathrm{R}^{2}=0.174\right)$. Thus, the null hypothesis is rejected because PsyCap (Self-Efficacy) and OC have a statistical relationship at the significance level of 0.01 .

\section{Research Finding}

Our findings support the view that the dimensions of PsyCap (hope, optimism, resilience, and self-efficacy) were positively related with JE (fit, links, and sacrifice). More PsyCap are more effective in achieving JE. High PsyCap will be more likely to achieve high profit. The high PsyCap would lead to more team success, more collective efficacy, better group communication, and more satisfaction of the group members.

The results of this research refer to a direct exponential influence relationship between the PsyCap and the level of JE among employees, as the low level of PsyCap reduced their agreement with the organization. This agrees with the findings of Rego et al., (2012) that the availability of a higher level of PsyCap will improve the quality of the relationship that links employees and heads at work, leading to the improvement of the level of JE, and reduction of negative reactions in the work environment. This result is consistent with the findings of Hayek (2012) the PsyCap plays a positive role in influencing the concept of risk of owners of small projects and motivates them to continue to evaluate and implement their investment ideas.

Several meta analytic studies have found a negative relationship between PsyCap and OC. The findings reveal that PsyCap among employees negatively influences OC. 
The results of this research refer to a relationship direct effect in the opposite direction between the PsyCap and $\mathrm{OC}$ of employees. These feelings of OC include (1) lower self-confidence, (2) the feeling that the management of the organization lacks integrity, and (3) the feeling that the management of the organization focuses primarily on its interests even if this conflicted with the interests of employees.

All of these beliefs negatively affected employees lowering the level of JS and spreading the spirit of apathy within the work environment. Add to this lack of attention to productivity. This confirms the findings of Neves (2012) that the phenomenon of cynicism has caused uneasiness for most organizations. Also, Apyadin (2012) pointed out that the high level of cynicism was the reason for the low level of the behavior of employees in the work environment.

\section{Research Implications}

\subsection{Theoretical Implications}

Despite its theoretical appeal and importance of PsyCap, we found no study that investigates the relationship between PsyCap, JE and OC in Egypt. The paper provides some extensions to the nascent theory of PsyCap by exploring its link with JE and OC.

\subsection{Practical Implications}

This study has some implications for managers. Managers can help their employees, through training interventions, to develop their PsyCap. It will help the employees to foster new ways of doing completing their assignments and tasks. High PsyCap individuals, due to their positive psychological resources, may appear as a competitive advantage to their organizations. Managers should be careful in assigning relatively stressful tasks to those who are low on PsyCap as these individuals are more likely to report job stress.

The practical implications include manager attention to building and strengthening the PsyCap of their workers. There are specific guidelines and numerous successful applications in the positive psychology literature for enhancing hope, optimism, resiliency, and self-efficacy.

Leadership can enhance the PsyCap in one's organization to improve performance and competitive advantage. Leaders can provide opportunities to build their own PsyCap and that of their associates through successful practice and performance.

Managers can invest in PsyCap through encouraging learning among employees. The more developed employees' positive psychological states become, the higher their PsyCap to draw from in dealing with the increasing demands and pressures of today's organizations.

PsyCap positively impact the JE of employees and contribute to an organization's competitive advantage. It is not enough just to provide a positive organizational climate to get optimal impact on JE. It may be important to recognize that the level of an employees' PsyCap may play a role in leveraging what a positive organizational climate can contribute to JE.

PsyCap can be a meaningful source of positive employee outcomes based on alignment with the supervisor; regardless of the absolute value of PsyCap. Managers may look for employees who are high in terms of PsyCap. Not only has PsyCap been shown to be directly related to higher levels of performance and job satisfaction, but it is also logical that employees who are more hopeful, resilient, optimistic, and confident can provide higher value to an organization than can employees lower in these psychological capacities.

Additionally, it would seem beneficial for managers to take measures to increase employees' identification with their organization, such as striving for a higher organizational purpose. In turn, this might enhance employees' feeling they are working for a higher good and higher moral standards, which can create feelings the organization is a worthy place to work. Organizations could reduce turnover by developing ways to increase the PsyCap similarity between a leader and his employees, organizations would garner the benefits of employees feeling more satisfied and fitting into the organizational culture.

PsyCap is an extension of human and social capital. An organization can increase its competitive advantage by developing and managing PsyCap amongst its employees.

\section{Recommendation}

1. The need to invest in PsyCap as a modern strategy for retention of employees and increasing the level of JE.

2. The need to focus on the four dimensions of PsyCap and using them to reduce the feelings of OC among employees. 
a. Hope, it is found out, affects the attitudes of employees and then influences the feelings of cynicism they have, where high levels of hope make employees contribute to the reduction of cynicism.

b. As for resilience, we find out that after an individual's ability to adapt and be flexible may affect the level of cynicism about the organization. Individuals who have a high capacity and flexibility to cope with stressful circumstances might have lower feelings of organizational cynicism.

c. As for optimism, we find that the level of an individual affects the level of his ability to deal with adverse events in the work environment and then controls the feelings of cynicism towards the organization.

d. As for the last dimension of self-efficacy, we find that the decline in self-efficacy makes an individual contribute significantly to the increase of cynicism towards the organization. On the contrary, we find that the higher self-efficacy is, the lower the feelings of OC.

3. The need to train leaders and managers on how to develop the four dimensions of PsyCap through training courses targeting the spread of the spirit of hope and optimism among managers, and equipping them with skills to deal with different situations in order to ensure the achievement of positive feedback in the work environment.

4. Menoufia University hospitals managers and leaders must attend development of the PsyCap as competitive advantage that can actualize very important goals such as reinforcement of meaning in work, organizational citizenship behavior, commitment, and performance.

5. Managing and increasing the level of PsyCap in Menoufia University hospitals requires deliberate interventions. For example, organisations can increase the level of PsyCap by using short training sessions of one to three hour micro interventions in which they measure PsyCap before and after the interventions.

6. Menoufia University hospitals can increase PsyCap through Strengths, Opportunities, Aspirations and Results (SOAR) a strategic thinking framework that integrates whole system and strengths-based perspectives to create a strategic transformation process with a focus on creating sustainable value to achieve desired performance results.

7. Menoufia University hospitals SOAR encourages their employees to work together to create a shared understanding of the status of the organisations and construct their futures through dialogue and commitment to action. Research confirms that using strengths-based interventions creates positive emotions with upward spirals toward optimal individual and organizational performance. SOAR is an example of a newer organization development practice that builds on the premise that organisations can use shared dialogue about systems' strengths and opportunities to shape preferred futures that allow for positive changes in strategies, structures, business models, systems and processes.

\section{Limitations of the Study}

There are some limitations of the study. Firstly, using a cross-sectional design limits the inference of causal relationships. Specifically, by not using experimental manipulation, random assignment or longitudinal analysis, the author could not infer causal effects between PsyCap, JE, and OC.

A second limitation concerns the theorized relationship between PsyCap, JE, and OC. Specifically, the study did not address other variables that may affect the relationship between PsyCap, JE, and OC.

The study examined the effects of PsyCap on JE and OC in the context of only one organization, and a limitation concerns generalizing results to other organisations. For example, in a comparative study that explored the role of PsyCap in Egypt public and private organisations,

A final limitation is common source bias. The researchers use the same sample to gather data on both independent and dependent variables. This method of obtaining data may result in common source bias and lead to inflated relationships. The author did not use these methods because of resource constraints about the ability to issue several surveys and use several observers.

\section{Future Research Directions}

Future research should incorporate other related measures to provide a more comprehensive understanding of the link between positive psychological resources and creativity or innovation related criterion variables.

Future research can be helpful by comparing the predictive ability of PsyCap with other creativity related personality characteristics to give an insight of the relative strengths of these dispositions. 
Future research should continue to use qualitative data, like data from focus groups, to investigate areas of organizational change at the team or business-unit level.

A longitudinal study would yield this information. For example, a longitudinal study could measure the ability of PsyCap to predict OCB before, during and after a significant change event. Longitudinal research designs are very critical to our understanding of the directions of influence between PsyCap and job outcomes. Finally, future research in the area of PsyCap would benefit from longitudinal studies in which researchers observe levels of PsyCap and OCB over time in the context of organizational change.

\section{Conclusion}

The results of this study not only suggest the seeming value of PsyCap at all levels within organizations, but also the benefits that may result from organizations providing positive, supportive climates.

Since PsyCap is "state-like" and there is at least preliminary evidence that it can be developed (Luthans et al., 2006), investing in and developing PsyCap may be an example of the new thinking and new approaches that are needed for the "flat world" environment facing today's organizations and their leaders.

The theoretical foundation was POS and the author measured positive resource strengths and capacities in the form of PsyCap. The study examined the effect of PsyCap on JE and OC. As an empirical analysis of PsyCap in a government organization that was undergoing a holistic change intervention, this study provides new information that organizations can use to increase positive outcomes. In addition to its practical applications, the study adds to the growing body of knowledge about POB in two ways. First, the author found a positive relationship between PsyCap and JE. Organization leaders should increase POB by managing PsyCap and its four positive PsyCap (hope, optimism, self-efficacy and resilience). Secondly, the author found a negative relationship between PsyCap and OC. Organization managers can reduce the OC by using the dimension of PsyCap.

\section{References}

Abraham, R. (2000). Organizational Cynicism: Bases and Consequences. Genetic, Social, and General Psychology Monographs, 126(3), 269-292.

Allen, D. G. (2006). Do organizational socialization tactics influence newcomer embeddedness and turnover? Journal of Management, 32, 237-256. http://dx.doi.org/10.1177/0149206305280103

Andersson, L. M. (1996). Employee cynicism: An examination using a contract violation framework. Human Relations, 49, 1395-1418. http://dx.doi.org/10.1177/001872679604901102

Andersson, L. M., \& Bateman, T. S. (1997). Cynicism in the workplace: some causes and effects. J. Organiza. Behav. 18 , http://dx.doi.org/10.1002/(SICI)1099-1379(199709)18:5<449::AID-JOB808>3.0.CO;2-O

Apyadin, C. (2012). Relationship between workplace bullying and organizational cynicism in Turkish public universities. African Journal of Business Management, 6(34), 9649-9657.

Arabac1, I. B. (2010). The Effects of Depersonalization and Organizational Cynicism Levels on the Job Satisfaction of Educational Inspectors. African Journal of Business Management, 4(13), 2802-2811.

Avey, J. B., Avolio, B. J., \& Luthans, F. (2011). Experimentally analyzing the impact of leader positivity on follower positivity and performance. The Leadership Quarterly, 22(2), 282-294. http://dx.doi.org/10.1016/j.leaqua.2011.02.004

Avey, J. B., Hughes, L. W., Norman, S. M., \& Luthans, K. (2008). Using positivity, transformational leadership and empowerment to combat employee negativity. Leadership and Organization Development Journal, 29, 110-126. http://dx.doi.org/10.1108/01437730810852470

Avey, J. B., Luthans, F., \& Youssef, C. M. (2010). The additive value of positive psychological capital in predicting work attitudes and behaviors. Journal of Management, 36, 430-452. http://dx.doi.org/10.1177/0149206308329961

Avey, J. B., Wernsing, T. S., \& Luthans, F. (2008). Can positive employees help positive organisational change? Impact of psychological capital and emotions on relevant attitudes and behaviors. The Journal of Applied Behavioral Science, 44(1), 48-70. http://dx.doi.org/10.1177/0021886307311470

Avolio, B. J., \& Luthans, F. (2006). The high impact leader: Moments matter for accelerating authentic leadership development. New York: McGraw-Hill. 
Bandura, A. (1986). Social foundations of thought and action: A social cognitive theory. Englewood Cliffs, NJ: Prentice Hall.

Bandura, A. (1997). Self-self efficacy: The exercise of control. New York: Freeman.

Bandura, A. (2000). Cultivate self-efficacy for personal and organizational effectiveness. In Locke EA (Ed.), The Blackwell handbook of principles of organizational behavior (pp. 120-136). Oxford, UK: Blackwell.

Bandura, A., \& Locke, E. A. (2003). Negative self-self efficacy and goal effects revisited. Journal of Applied Psychology, 88, 87-99. http://dx.doi.org/10.1037/0021-9010.88.1.87

Bauer, T. N., Bodner, T., Erdogan, B., Truxillo, D. M., \& Tucker, J. S. (2007). Newcomer adjustment during organizational socialization: A metaanalytic review of antecedents, outcomes, and methods. Journal of Applied Psychology, 92(3), 707-721. http://dx.doi.org/10.1037/0021-9010.92.3.707

Brandes, P., Dharwadkar, R., \& Dean, J. W. (1999). Does Organizational Cynicism Matter? Employee and Supervisor Perspectives on Work Outcomes. Eastern Academy of Management Proceedings, 150-153.

Brockway, J. H., Carlson, K. A., Jones, S. K., \& Bryant, F. B. (2002). Development and validation of a scale for measuring cynical attitudes toward college. Journal of Educational Psychology, 94, 210-224. http://dx.doi.org/10.1037/0022-0663.94.1.210

Bruch, C., \& Vogel, B. (2006). Emotion as mediators of the relations between perceived supervisor support and psychological hardiness on employee cynicism. J. Organiza. Behav. 27, 463-484. http://dx.doi.org/10.1002/job.381

Bryant, F. B., \& Cvengros, J. A. (2004). Distinguishing hope and optimism: Two sides of a coin, or two separate coins? Journal of Social and Clinical Psychology, 23(2), 273-302. http://dx.doi.org/10.1521/jscp.23.2.273.302

Careless, S. A. (2005). Person-job fit versus person-organization fit as predictors of organizational attraction and job acceptance intentions: A longitudinal study. Journal of Occupational and Organizational Psychology, 78, 411-429. http://dx.doi.org/10.1348/096317905X25995

Carver, C. S., \& Scheier, M. S. (2002). Optimism. In C. R. Snyder \& S. J. Lopez (Eds.), Handbook of positive psychology (pp. 231-243). Oxford, United Kingdom: Oxford University Press.

Cetin, F. (2011). The Effect of the Organizational Psychological Capital on theAttitudes of Commitment and Satisfaction: a Public Sample in Turkey. European Journal of Social Science, 21(3), 373-380.

Cetin, F., \& Basim, H. N. (2011). Psikolojik Dayanıklılı̆̆ın İş Tatmini ve Örgütsel Bağlllık Tutumlarındaki Rolü. “iş, GÜÇ” Endüstri İlişkileri ve İnsan Kaynakları Dergisi, 13(3), 79-94.

Chang, E. C., Rand, K. L., \& Strunk, D. R. (2000). Optimism and risk for job burnout among working college students: stress as a mediator. Personality and Individual Differences, 29(2), 255-263. http://dx.doi.org/10.1016/S0191-8869(99)00191-9

Chatman, J. A. (1989). Improving interactional organizational research: A model of person-organization fit. Academy of Management Review, 14(3), 333-349.

Cho, D.-H., \& Son, J.-M. (2011). Job Embeddedness and Turnover Intentions: An Empirical Investigation of Construction IT Industries. International Journal of Advanced Science and Technology, 40, 101-110.

Cohler, B. J. (1987). Adversity, resilience, and the study of lives. In A. E. James \& B. J. Cohler (Eds.), The invulnerable child (pp. 363-424). New York.

Coutu, D. L. (2002). How resilience works. Harvard Business Review, 80(3), 46-55.

Culbertson, S. S., Fullager, C. J., \& Mills, M. J. (2010). Feeling good and doing great: The relationship between psychological capital and well-being. Journal of Occupational Health Psychology, 15, 421-433. http://dx.doi.org/10.1037/a0020720

Dean, J. W., Brandes, P., \& Dharwadkar, R. (1998). Organizational cynicism. Academy of Management Review, $23,341-352$.

Derya, Ö. E., \& Ceren, A. G. (2011). A research to determine the relationship between organizational cynicism and burnout levels of employees in health sector. Business and Management Review, 1(4), 26-38.

Derya, Ö. E., Ceren, A. G., \& Meltem, Ş. D. (2010). Örgütlerde Sinizm Güvensizlikle Mi Bulaşır? Organizasyon ve Yönetim Bilimleri Dergisi, 2(2), 47-57. 
Felps, W., Hekman, D. R., Mitchell, T. R., Lee, T. W., Harman, W. S., \& Holtom, B. C. (2009). Turnover contagion: How coworkers' job embeddedness and coworkers' job search behaviors influence quitting. Academy of Management Journal, 52, 545-561. http://dx.doi.org/10.5465/AMJ.2009.41331075

Fields, D., Dingman, M. E., Roman, P. M., \& Blum, T. C. (2005). Exploring predictors of alternative job changes. $\begin{array}{lllll}\text { Journal of Occupational and Organizational Psychology, } & 78,82 .\end{array}$ http://dx.doi.org/10.1348/096317904X22719

Fredrickson, B. L. (2004). The broaden-and-build theory of positive emotions. Phil. Trans. Royal Society. London. B, 359, 1367-1377. http://dx.doi.org/10.1098/rstb.2004.1512

Fry, P. S. (1995). Perfectionism, humor and optimism as moderators of health outcomes and determinants of coping styles of women executives. Genetic, Social and General Psychology Monographs, 121(2), 211-245.

Gamze, K. (2009). Araştırma Görevlilerinin Örgütsel Destek Algıları İle Örgütsel Sinizm Tutumları Arasındaki İlişki, Yayınlanmamış Yüksek Lisans Tezi, Akdeniz Üniversitesi Sosyal Bilimler Enstitüsü.

Gohel, K. (2012). Psychological Capital as a Determinant of Employee Satisfaction. International Referred Research Journal, 3(36), 34-37.

Gooty, J., Gavin, M., Johnson, P. D., Frazer, M. L., \& Snow, D. B. (2009). In the Eyes of the Beholder. Transpofrmational Leadership, Positive Psychological Capital, and Performance. Journal of Leadership \& Organizational Studies, 15(4), 353-367. http://dx.doi.org/10.1177/1548051809332021

Granovetter, M. (1985). Economic Action and Social Structure: The Problem of Embeddedness. The American Journal of Sociology, 91(3), 481-510. http://dx.doi.org/10.1086/228311

Harris, G. E., \& Cameron, J. E. (2005). Multiple dimensions of organizational identification and commitment as predictors of turnover intentions and psychological well-being. Canadian Journal of Behavioural Science, 37(3), 159-169. http://dx.doi.org/10.1037/h0087253

Hayek, M. (2012). Control Beliefs and Positive Psychological Capital Can Nascent Entrepreneurs Discriminate Between What Can and Control be Controlled? Journal of Management Research, 12(1), 3-13.

Hodges, T. D. (2010). An Experimental Study of the impact of psychological capital on performance, engagement, and the contagion effect. Dissertations and Theses from the College of Business Administration, University of Nebraska - Lincoln Year 2010

Holtom, B. C., \& Inderrieden, E. J. (2006). Integrating the unfolding model and job embeddedness model to better understand voluntary turnover. Journal of Managerial Issues, 18, 435-452.

Irshad, A., \& Toor, S. R. (2008). Problems and Challenges in Human Resource Management: A Case of Large Organization in Pakistan. Pakistan Journal of Commerce and Social Sciences, 1, 37-47.

Johnson, J. L., \& O"leary-Kelly, A. M. (2003). The Effects Of Psychological Contract Breach and Organizational Cynicism: Not All Social Exchange Violations Are Created Equal. Journal of Organizational Behavior, 24, 627-647. http://dx.doi.org/10.1002/job.207

Judge, T. A., Jackson, C. L., Shaw, C. V., Scott, B. A., \& Rich, B. L. (2007). Self-Efficacy and Work-Related Performance: The Integral Role of Individual Differences. Journal of Applied Psychology, 92, 107-127. http://dx.doi.org/10.1037/0021-9010.92.1.107

Karatepe, O. M., \& Ngeche, R. N. (2011). Does Job Embeddedness Mediate the Effect of Work Engagement on Job Outcomes?: A Study of Hotel Employees in Cameroon. Journal of Hospitality Marketing and Management.

Keles, H. N. (2011). Pozitif Psikolojik Sermaye: Tanımı, Bileşenleri ve Örgüt Yönetimine Etkileri. Organizasyon ve Yönetim Bilimleri Dergisi, 3(2), 343-350.

Klohnen, E. C. (1996). Conceptual analysis and measurement of the construct of ego-resiliency. Journal of Personality and Social Psychology, 70, 1067-1079. http://dx.doi.org/10.1037/0022-3514.70.5.1067

Kluemper, D. H., Little, L. M., \& DeGroot, T. (2009). State or trait: Effects of state optimism on job-related outcomes. Journal of Organizational Behavior, 30, 209-231. http://dx.doi.org/10.1002/job.591

Kutanis, R. Ö., \& Çetinel, E. (2009). Adaletsizlik Algısı Sinizmi Tetikler mi?: Bir Örnek Olay”, 17. Ulusal Yönetim ve Organizasyon Kongresi Bildiri Kitabı, Eskişehir, pp. 693-699.

Lee, R. T., \& Ashforth, B. T. (1996). A meta-analytic examination of the correlates of the three dimensions of job burnout. Journal of Applied Psychology, 81(2), 123-133. http://dx.doi.org/10.1037/0021-9010.81.2.123 
Lee, T. W., Mitchell, T. R., Sablynski, C. J., Burton, J. P., \& Holtom, B. C. (2004). The effects of organizational embeddedness on organizational citizenship, job performance, volitional absences, and voluntary turnover. Academy of Management Journal, 47, 711-722. http://dx.doi.org/10.2307/20159613

Lewis, P. (1985). Defining business ethics: like nailing jello to a wall. Journal of Business Ethics, 4, 377-383. http://dx.doi.org/10.1007/BF02388590

Lewis, S. (2011). Positive Psychology at Work. West Sussex: John Wiley \& Sons Ltd. http://dx.doi.org/10.1002/9781119990390

Lim, V. K. G., \& Loo, G. L. (2003). Effects of parental job insecurity and parenting behaviors on youth's self-efficacy and work attitudes. Journal of Vocational Behavior, 63, 86-98. http://dx.doi.org/10.1016/S0001-8791(02)00020-9

Luthan, F., Luthans, K. W., \& Luthans, B. C. (2004). Positive Psychological Capital, Beyond Human \& Social Capital. Business Horizons, 41, 45-50. http://dx.doi.org/10.1016/j.bushor.2003.11.007

Luthans, F, \& Youssef, C. M. (2007). Emerging positive organizational behavior. Journal of Management, 33, 321-349. http://dx.doi.org/10.1177/0149206307300814

Luthans, F. (2002). Positive organizational behavior: Developing and managing psychological strengths for performance improvement. Academy of Management Executive, 16(1), 57-72. http://dx.doi.org/10.5465/AME.2002.6640181

Luthans, F. (2010). Organizational Behavior An Evidence-Based Approach (12th ed.). McGraw-Hill/Irwin.

Luthans, F., \& Church, A. H. (2002). Positive organizational behaviour: Developing and managing psychological strengths. Academy of Management Executive, 16(1), 57-72. http://dx.doi.org/10.5465/AME.2002.6640181

Luthans, F., \& Youssef, C. (2004). Human, Social, and Now Positive Psychological Capital Management: Investing in People for Competitive. Advantage - Organizational Dynamics, 33(2), 143-160. http://dx.doi.org/10.1016/j.orgdyn.2004.01.003

Luthans, F., \& Youssef, C. M. (2004). Human, social and now positive psychological capital management: Investing in people for competitive advantage.

Luthans, F., Avey, J. B., \& Patera, J. L. (2008). Experimental analysis of a Web-based intervention to develop positive psychological capital. Journal of Academy of Management Learning and Education, 7(2), 209-221. http://dx.doi.org/10.5465/AMLE.2008.32712618

Luthans, F., Avey, J. B., Avolio, B. J., Norman, S., \& Combs, G. (2006). Psychological capital development: Toward a micro-intervention. Journal of Organizational Behavior, 27, 387-393. http://dx.doi.org/10.1002/job.373

Luthans, F., Avolio, B. J., Walumba, F. O., \& Li, W. (2005). The psychology capital of Chinese workers: Exploring the relationship with performance. Management and Organization Review, 1(2), 249-271. http://dx.doi.org/10.1111/j.1740-8784.2005.00011.x

Luthans, F., Avolio, B., Walumbwa, F., \& Li, W. (2005). The psychological capital of Chinese workers: Exploring the relationship with performance. Management and Organization Review, 1, 247-269. http://dx.doi.org/10.1111/j.1740-8784.2005.00011.x

Luthans, F., Luthans, K. W., \& Luthans, B. (2004). Positive psychological capital: Beyond human and social capital. Business Horizons, 47(1), 45-50. http://dx.doi.org/10.1016/j.bushor.2003.11.007

Luthans, F., Norman, S. M., Avolio, B. J., \& Avey, J. B. (2008). The mediating role of psychological capital in the supportive organizational climate-employee performance relationship. Journal of Organizational Behavior, 29(2), 219-238. http://dx.doi.org/10.1002/job.507

Luthans, F., Youss ef, C. M., \& Avolio, B. J. (2007). Psychological capital, developing the human competitive edge. Oxford: Oxford University Press.

Luthans, F., Youssef, C., \& Avolio, B. J. (2007). Investing and developing positive organizational behavior. The emergence of psychological capital. In C. L. Cooper \& D. Nelson (Eds.), Positive organizational behavior: Accentuating the positive at work (pp. 9-24). Thousand Oaks, CA: Sage. http://dx.doi.org/10.4135/9781446212752.n2

Lyubomirsky, S., King, L., \& Diener, E. (2005). The benefits of frequent positive affect: Does happiness lead to success? Psychol Bull, 131(6), 803-855. http://dx.doi.org/10.1037/0033-2909.131.6.803 
Martin, K., Sarrzon, P. G., Peterson, C., \& Famose, J. P. (2003). Explanatory style and resilience after sports $\begin{array}{lllll}\text { failure. Personality and Individual Differences, } & 35, & \text { 1685-1695. }\end{array}$ http://dx.doi.org/10.1016/S0191-8869(02)00390-2

Masten, A. S. (1994). Resilience in individual development: Successful adaptation despite risk and adversity. In M. C. Wang \& E. W. Gordon (Eds.), Risk and resilience in inner city America: Challenges and prospects (pp. 3-25). Hillsdale, NJ: Lawrence Erlbaum Associates, Inc.

Masten, A. S. (2001). Ordinary magic: Resilience processes in development. American Psychologist, 56, 227-239. http://dx.doi.org/10.1037/0003-066X.56.3.227

Masten, A. S., \& Reed, M. G. J. (2002). Resilience in development. In C. R. Snyder \& S. J. Lopez (Eds.), Handbook of positive psychology (pp. 74-88). Oxford, UK: Oxford University Press.

Mitchell, T. R., Holtom, B. C., Lee, T. W., Sablynski, C. J., \& Erez, M. (2001). Why people stay: Using organizational embeddedness to predict voluntary turnover. Academy of Management Journal, 44, 1102-1121. http://dx.doi.org/10.2307/3069391

Nair, P., \& Kamalanabhan, J. (2010). The Impact of Cynicism on Ethical Intentions of Indian Managers: The moderating Role of Seniority. Journal of International Business Ethics, 3(1), 4-29.

Neves, P., (2012). Organizational Cynicism: Spillover effects performance. The Leadership Quarterly, 23, 965-976. http://dx.doi.org/10.1016/j.leaqua.2012.06.006

Ng, T. W., \& Feldman, D. C. (2009). Occupational embeddedness and job performance. Journal of Organizational Behavior, 30, 863-891. http://dx.doi.org/10.1002/job.580

O’Brien, A. T., Haslam, S. A., Jetten, J., Humphrey, L., O’Sullivan, L., \& Postmes, T. (2004). Cynicism and disengagement among devalued employee groups: The need to ASPIRe. Career Development International, 9(1), 28-44. http://dx.doi.org/10.1108/13620430410518129

O'Leary, B. S., Lindholm, M. L., Whitford, R. A., \& Freeman, S. E. (2002). Selecting the best and brightest: Leveraging human capital. Human Resource Management, 41, 325-340. http://dx.doi.org/10.1002/hrm.10044

Özkalp, E. (2009). “Örgütsel Davranışta Yeni Bir Boyut: Pozitif (Olumlu) Örgütsel Davranış Yaklaşımı ve Konuları”, 17. Ulusal Yönetim ve Organizasyon Kongresi Bildiriler Kitabı, Eskişehir Osmangazi Üniversitesi, Eskişehir, 21-23 Mayıs: 491-497.

Park, K., \& Lee, K. E. (2004). A Study on the Relationship between Job Embeddedness and Turnover Intention in Korea. Korean Management Review, 33, 5.

Peterson C. (2000). The future of optimism. American Psychologist, 55, 44-55. http://dx.doi.org/10.1037/0003-066X.55.1.44

Peterson, S. J., Luthans, F., Avolio, B. J., Walumbawa, F. O., \& Zhang, Z. (2011). Psychological Capital and Employee Performance: A Latent Growth Modeling Approach. Personnel Psychology, 64, 427-450. http://dx.doi.org/10.1111/j.1744-6570.2011.01215.x

Peterson, S. J., Walumbwa F. O., Byron, K., \& Myrowitz, J. (2008). CEO Positive Psychological Traits, Transformational Leadership, and Firm Performance in High-Technology Start-up and Established Firms. Journal of Management. http://dx.doi.org/10.1177/0149206307312512

Rego, A., Sousa, F., Marques, C., \& Cunha, M., (2012). Authentic leadership promoting employees' psychological capital and creativity. Journal of Business Research, 65(3), 429-437. http://dx.doi.org/10.1016/j.jbusres.2011.10.003

Reicher, A. E., Wanous, J. P., \& Austin, J. T. (1997). Understanding and managing cynicism about organizational change. Academy of Management Executive, 11(1), 48-59.

Schneider, B. (2001). Fits about fit. Applied Psychology: An International Review, 50(1), 141-152. http://dx.doi.org/10.1111/1464-0597.00051

Seligman, M. E. P. (1998). Learned optimism. New York: Pocket Books.

Shahnawaz, M. G., \& Jafri, M. H. (2009). Psychological capital as predictors of organizational commitment and organizational citizenship behaviour. Journal of the Indian Academy of Applied Psychology, 35, 78-84.

Shaw, J. D., Delery, J. E., Jenkins Jr., G. D., \& Gupta, N. (1998). An organization-level analysis of voluntary and involuntary turnover. Academy of Management Journal, 41(5), 511-525. http://dx.doi.org/10.2307/256939 
Snow, J. L. (2002). Enhancing work climate to improve performance and retain valued employees. J Nurs Adm. 32(7/8), 393-397. http://dx.doi.org/10.1097/00005110-200207000-00007

Snyder, C. R. (1994). The psychology of hope: You can get there from here. New York: Free Press.

Snyder, C. R. (2000). Handbook of hope. San Diego: Academic Press.

Snyder, C. R., \& Lopez, S. (2002). Handbook of positive psychology. Oxford, UK: Oxford University Press.

Snyder, C. R., \& Lopez, S. (Eds.). (2002). Handbook of positive psychology. Oxford, United Kingdom: Oxford University Press.

Snyder, C. R., Irving, L., \& Anderson, J. (1991). Hope and health: Measuring the will and the ways. In C. R. Snyder \& D. R. Forsyth (Eds.), Handbook of social and clinical psychology (pp. 285-305). Elmsford, NY: Pergamon.

Snyder, C. R., Lapointe, A. B., Crowson, J. J., Jr., \& Early, S. (1998). Preferences of high- and low-hope people for self-referential input. Cognition and Emotion, 12, 807-823. http://dx.doi.org/10.1080/026999398379448

Snyder, C. R., Rand, K. L., \& Sigmon, D. R. (2002). Hope theory. In C. R. Snyder \& S. Lopez (Eds.), Handbook of positive psychology (pp. 257-276). Oxford: United Kingdom: Oxford University Press.

Snyder, C. R., Sympson, S. C., Ybasco, F. C., Borders, T. F., Babyak, M. A., \& Higgins, R. L. (1996). Development and validation of the state hope scale. Journal of Personality and Social Psychology, 70(2), 321-335. http://dx.doi.org/10.1037/0022-3514.70.2.321

Stajkovic \& Luthans. (1998). Self-efficacy and work-related performance: A meta-analysis. Psychological Bulletin, 124, 240-261. http://dx.doi.org/10.1037/0033-2909.124.2.240

Strutton, D., \& Lumpkin, J. (1992). Relationship between optimism and coping strategies in the work environment. Psychological Reports, 71, 1179-1187. http://dx.doi.org/10.2466/pr0.1992.71.3f.1179

Taunton, R. L., Boyle, D. K., Woods, C. Q., Hansen, H. E., \& Bott, M. J. (1997). Manager leadership and retention of hospital staff nurses. West $J$ Nurs Res. 19(2), 205-226. http://dx.doi.org/10.1177/019394599701900206

Tierney, P., \& Farmer, S. M. (2002). Creative self-efficacy: Its potential antecedents and relationship to creative performance. Academy of Management Journal, 45(6), 1137-1148. http://dx.doi.org/10.2307/3069429

Toor, S., \& Ofori, G. (2010). Positive Psychological Capital as a Source of Sustainable Competitive Advantage for Organizations. Journal of Construction Engineering and Management, 136(3), 1-12. http://dx.doi.org/10.1061/(ASCE)CO.1943-7862.0000135

Tugade, M. M., \& Fredrickson, B. L. (2004). Resilient individuals use positive emotions to bounce back from negative emotional experiences. Journal of Personality and Social Psychology, 86, 320-333. http://dx.doi.org/10.1037/0022-3514.86.2.320

Tugade, M. M., Fredrickson, B. L., \& Barrett, L. F. (2004). Psychological resilience and positive emotional granularity. Journal of Personality, 72, 1161-1190. http://dx.doi.org/10.1111/j.1467-6494.2004.00294.x

Turner, J. H., \& ve Valentine, S. R. (2001). Cynicism as a fundamental dimension of moral decision-making: a scale development. J. Bus. Ethics, 34, 123-136. http://dx.doi.org/10.1023/A:1012268705059

Urbany, J. E. (2005). Inspiration and cynicism in values statements. J. Bus. Ethics, 62, 169-182. http://dx.doi.org/10.1007/s10551-005-0188-2

Valle, M., Leupold, C., \& Leupold, K., (2006). Holding On and Letting Go: The Relationship Between Job Embeddedness and Turnover Among PEM Physicians. Journal of Business Inquiry, 3-10.

Villanova, P., Bernardin, H., Johnson, D., \& Dahmus, S. (1994). The validity of a measure of job compatibility in the prediction of job performance and turnover of motion picture theater personnel. Personnel Psychology, 47, 73-90. http://dx.doi.org/10.1111/j.1744-6570.1994.tb02410.x

Wanous, J. P., Reichers, A. E., \& Austin, J. T. (2000). Cynicism about organizational change: Measurement, antecedents, and correlates. Group and Organization Management. http://dx.doi.org/10.1177/1059601100252003

Wrosch, C., \& Scheier, M. F. (2003). Personality and Quality of Life: The Importance of Optimism and Goal Adjustment. Quality of Life Research, 12(1), 59-72. http://dx.doi.org/10.1023/A:1023529606137 
Youssef, C. M., \& Luthans, F. (2010). An integrated model of psychological capital in the workplace. In P. A. Linley, S. Harrington, \& N. Garcea (Eds.), Oxford handbook of positive psychology and work (pp. 277-288). New York: Oxford University Press.

Youssef, C. M., \& Luthans, F. (2012). Psychological capital: Meaning, findings, and future directions. In K. S. Cameron \& G. M. Spreitzer (Eds.), The Oxford handbook of positive organizational scholarship (pp. 17-27). New York, NY: Oxford University Press.

Zhou, J., \& George, J. M. (2003). Awakening employee creativity: The role of leader emotional intelligence. The Leadership Quarterly, 14, 545-568. http://dx.doi.org/10.1016/S1048-9843(03)00051-1

\section{Copyrights}

Copyright for this article is retained by the author(s), with first publication rights granted to the journal.

This is an open-access article distributed under the terms and conditions of the Creative Commons Attribution license (http://creativecommons.org/licenses/by/3.0/). 